http://jmscr.igmpublication.org/home/

ISSN (e)-2347-176x ISSN (p) 2455-0450

crossref DOI: https://dx.doi.org/10.18535/jmscr/v9i4.08

Journal Of Medical Science And Clinical Research

IGM Publication

An Official Publication of IGM Publication

\title{
Diagnostic Value of WBC, CRP, Procalcitonin in Acute Appendicits
}

Authors

\author{
Dr Manikandan G*, Dr Chandrashekar N, Dr Jagannath, Dr Sharath T R \\ Sri Siddhartha Medical College Hospital \& Research Centre, Agalakote, Tumkur, Karnataka \\ *Corresponding Author
}

Dr Manikandan G

Junior Resident, Department of General Surgery, SSMC, Tumkur, India

\begin{abstract}
Aims and Objectives

- To analyze the diagnostic value of WBC count, C REACTIVE PROTEIN and PROCALCITONIN in acute appendicitis.

- To determine the WBC count, $C$ reactive protein and Procalcitonin values in Acute appendicitis.

- To evaluate sensitivity, specificity, positive predictive value,negative predictive value of WBC count, $C$ reactive protein, Procalcitonin in acute appendicitis.

Materials and Methods: A sample of 42 patients were selected using universal sampling and a prospective study was conducted. The patients with right iliac fossa pain and symptoms of acute appendicitis at the department of General surgery of Sri Siddhartha Medical College Hospital and research Centre from September 2018 to April 2020. Then the sample is subjected to WBC count, CRP, Procalcitonin levels and Histopathological report. Then the sensitivity, specificity, PPV and NPV of the above mentioned parameters are assessed.

Conclusion: We found that elevated serum CRP, Procalcitonin levels and WBC support the surgeon's clinical diagnosis. We recommend CRP and procalcitonin measurement as a routine laboratory test in patients with suspected diagnosis of acute appendicitis. And we suggest that patients with lower abdominal pain and not clinically convincing and in the absence of increased inflammatory markers to undergo further imaging.
\end{abstract}

\section{Introduction}

Acute appendicitis is one of the most common emergency surgical admissions, with a lifetime prevalence of one in seven. Appendicectomy accounts for approximately $10 \%$ of all emergency abdominal procedures. The diagnosis of appendicitis is based on history, clinical examination, basic laboratory investigation and USG abdomen and pelvis and or CECT abdomen and pelvis. However, the definitive diagnosis is made on histology ${ }^{1}$.

The Alverado scoring system is a clinical scoring system that can be applied to a patient to support a clinical diagnosis of appendicitis. A Score of 5 or 6 is compatible with the clinical diagnosis of acute appendicitis. However, histology remains the gold standard for definitive diagnosis. Various papers have advocated the use of the Alverado scoring system in supporting the diagnosis of acute appendicitis, but few papers have looked at WBC 
and CRP levels as comparative markers.

Many have concluded that there is no significance in the WBC or CRP levels, others imply that together they enhance the predictive value of appendicitis. ${ }^{3,4}$

Recently several studies have explored the role of procalcitonin in diagnosis of acute appendicitis. Procalcitonin, a precursor of calcitonin is secreted by $\mathrm{C}$ cells of thyroid gland and $\mathrm{K}$ cells of the lung, in healthy individual procalcitonin is undetectable. This study aims to assess the clinical usage of pre operative WBC, CRP and Procalcitonin levels, and their relationship, if any, in patients with suspected appendicitis. ${ }^{2,5}$

\section{Materials \& Methods}

A prospective study included 42 patients with complaints of pain in right iliac fossa with suspected features of acute appendicitis will be enrolled for the study after obtaining written and informed consent satisfying all inclusion and exclusion criteria mentioned below after obtaining clearance from the ethical committee

\section{Inclusion Criteria}

All patients of acute appendicitis, of all age group and sex, based on clinical examination supplemented with USG examination of abdomen and pelvis and /or CECT abdomen and pelvis.

\section{Exclusion Criteria}

- Interval appendicectomy

- Appendicular mass

- Appendicular perforative peritonitis

\section{Methods of Collection of Data}

All data for the proposed study will be collected from the patients presenting to the outpatient and inpatient department of general surgery, Sri Siddhartha Medical College Hospital \& Research centre, Tumkur from November 2018 - November 2020

A detailed information sheet regarding the study at hand will give to the patient along with a verbal explanation in the language which the patient understands. Written informed consent will be obtained from all the patients before their enrolment into the study.

The data on socio-demographic details \& history will be collected using a pre-tested profoma by primary investigator (Dr.Manikandan.G) through personal interview. This will be followed by thorough clinical examination. Then the sample is subjected to WBC count, CRP, Procalcitonin levels and Histopathological report. The findings are recorded in the profoma sheet. Data collected will be enetered and tabulated in MS Excel spread sheet (version 2010).

\section{Statistical Analysis}

All quantitative parameters will be described through descriptive statistics such as mean and standard deviation. Sensitivity, Specificity, Positive Predictive Value, Negative Predictive Value of WBC count, CRP, Procalcitonin will be estimated with surgical findings and histopathological findings.

\section{Results}

Table 1: Age Distribution

\begin{tabular}{|l|c|c|c|}
\hline \multirow{2}{*}{ Age } & ACUTE APPENDICITIS & $\begin{array}{c}\text { GANGRENOUS } \\
\text { APPENDICITS }\end{array}$ & \multirow{2}{*}{$\begin{array}{c}\text { P VALUE } \\
\text { Chi }^{2} \text { test }\end{array}$} \\
\cline { 2 - 3 } & No (\%) & No $(\%)$ & \multirow{2}{*}{ 0.001* } \\
$11-2$ & $3(8.1)$ & $4(80)$ & \\
\hline $21-30$ years & $22(59.5)$ & $1(20)$ & \\
\hline $31-40$ years & $10(27)$ & 0 & \\
\hline $41-50$ & $2(5.4)$ & 0 & \\
\hline Total & 37 & 5 & \\
\hline
\end{tabular}


Table 2: Sex Distribution

\begin{tabular}{|l|c|c|c|}
\hline \multirow{3}{*}{ SEX } & $\begin{array}{c}\text { ACUTE } \\
\text { APPENDICITIS }\end{array}$ & $\begin{array}{c}\text { GANGRENOUS } \\
\text { APPENDICITS }\end{array}$ & $\begin{array}{c}\text { P VALUE } \\
\text { Chi }^{2} \text { test }\end{array}$ \\
\cline { 2 - 3 } & No $(\%)$ & No $(\%)$ & \multirow{2}{*}{$\mathbf{0 . 7 1 6}$} \\
\hline MALE & $19(51.4)$ & $3(60)$ & \multirow{2}{*}{ FEMALE } \\
\hline TEtal & $18(48.6)$ & $2(40)$ & \\
\hline Total & 37 & 5 & \\
\hline
\end{tabular}

Table 3: Crp Distribution

\begin{tabular}{|l|c|c|c|}
\hline CRP & $\begin{array}{c}\text { ACUTE } \\
\text { APPENDICITIS }\end{array}$ & $\begin{array}{c}\text { GANGRENOUS } \\
\text { APPENDICITS }\end{array}$ & $\begin{array}{c}\text { P VALUE } \\
\text { Chi }^{2} \text { test }\end{array}$ \\
\cline { 2 - 3 } & No $(\%)$ & No $(\%)$ & \multirow{2}{*}{$\mathbf{0 . 5 9 6}$} \\
\hline NORMAL & 0 & $1(25)$ & \multirow{2}{*}{} \\
\hline ABNORMAL & $37(100)$ & $4(75)$ & \\
\hline Total & 37 & 5 & \\
\hline
\end{tabular}

Table 4: WBC Distribution

\begin{tabular}{|l|c|c|c|}
\hline & $\begin{array}{c}\text { ACUTE } \\
\text { APPENDICITIS }\end{array}$ & $\begin{array}{c}\text { GANGRENOUS } \\
\text { APPENDICITS }\end{array}$ & $\begin{array}{c}\text { P VALUE } \\
\text { Chi }^{2} \text { test }\end{array}$ \\
\cline { 2 - 3 } & No $(\%)$ & No $(\%)$ & \multirow{2}{*}{} \\
\cline { 1 - 3 } NORMAL & $2(5.4)$ & $2(40)$ & \multirow{2}{*}{$\mathbf{0 . 7 1 6}$} \\
\hline ABNORMAL & $35(94.6)$ & $3(60)$ & \\
\hline Total & 37 & 5 & \\
\hline
\end{tabular}

Table 5: Procalcitonin Distribution

\begin{tabular}{|l|c|c|c|}
\hline & $\begin{array}{c}\text { ACUTE } \\
\text { APPENDICITIS }\end{array}$ & $\begin{array}{c}\text { GANGRENOUS } \\
\text { APPENDICITS }\end{array}$ & \multirow{2}{*}{$\begin{array}{c}\text { P VALUE } \\
\text { Chi }^{2} \text { test }\end{array}$} \\
\cline { 2 - 3 } & No $(\%)$ & No $(\%)$ & \multirow{2}{*}{} \\
\hline NORMAL & $1(2.7)$ & $1(25)$ & \multirow{2}{*}{$\mathbf{0 . 7 1 6}$} \\
\hline ABNORMAL & $36(97.3)$ & $4(75)$ & \\
\hline Total & 37 & 5 & \\
\hline
\end{tabular}

Table 6: Mean comparison of parameters among groups

\begin{tabular}{|l|c|c|c|}
\hline & $\begin{array}{c}\text { ACUTE } \\
\text { APPENDICITS }\end{array}$ & $\begin{array}{c}\text { GANGRENEOUS } \\
\text { APPENDICITIS }\end{array}$ & P value \\
\cline { 2 - 4 } & Mean \pm S.D & Mean \pm S.D & \\
\hline AGE & $28.8 \pm 6.1$ & $19 \pm 1.4$ & $0.002^{* *}$ \\
\hline CRP & $18.2 \pm 13$ & $8.8 \pm 3.7$ & $0.001^{* *}$ \\
\hline WBC & $13.3 \pm 21$ & $11.1 \pm 18.9$ & $0.02^{* *}$ \\
\hline PROCALCITONIN & $21.1 \pm 9.7$ & $12.9 \pm 2.9$ & $0.05^{* *}$ \\
\hline
\end{tabular}

\section{Discussion}

Diagnosis of patients with appendicitis is a big challenge in emergency department therefore a lot of negative appendectomies have been observed. A correct and early diagnosis of the disease is vital to decrease its morbidity of perforated cases and also to prevent unnecessary surgery for misdiagnosed cases.

In the present study of 42 patients, 22(52.3\%) were male and $20(47.7 \%)$ were female and the mean age was $26.7 \pm 6.7$ years ( range, 18 to 46 ) whereas in a study by Bulent kaya et al , Of 78 patients, $54(69.2 \%)$ were male and $24(30.8 \%)$ were female, and the mean age was $25.4 \pm 11.1$ years (range, 18 to 69 years) $^{3}$.In a study by Satendra Kumar et al of 65 patients, $46(70.8 \%)$ were male and 19(29.2\%) were female, and the mean age was $31.18 \pm 14.59$ years(range 15 to 65 years $)^{32}$.Also in a study by Essam et al of 100 patients, males were $60(60 \%)$ and females 
$40(40 \%)$, and the age range was $20-55$ years $^{9}$.

In our study the proportion of patients with suspected appendicitis had increased leukocyte count (white blood cell count) in 38(90.4\%) patients, where as in study by Bulent kaya et al 66 (84.6\%) patients had increased leukocyte count (white blood cell count) ${ }^{30}$. further, in study by Satendra Kumar et al elevated leukocyte count was present in $53(81.5 \%)$ patients. $^{8}$

In our study the WBC as maker for acute appendicitis showed that it has a sensitivity of $94 \%$ and specificity of $40 \%$, where as in a study by Essam et al the WBC as a marker for acute appendicitis showed a sensitivity of $85 \%$ and specificity of $75 \%{ }^{9}$

In our study it was shown that WBC had a positive predictive value of $90 \%$ and a negative predictive value of $50 \%$, whereas in a study by Essam et al WBC had a positive predictive value of $44 \%$ and a negative predictive value of $100 \%{ }^{9}$. In our study the CRP values were higher than the upper limit in 41(97.6\%) patients where as in the study by Bulent kaya et al the CRP values were higher than the upper normal limit in 54 (69.2\%) patients. also in study by Satendra Kumar et al elevated CRP level was present in 59(90.8\%) patients. ${ }^{8}$

Our study showed that the specificity and sensitivity of CRP as a diagnostic test in acute appendicitis is $80 \%$ and $95 \%$ respectively, whereas in a study by Essam et al it was shown that the specificity and sensitivity of CRP as a diagnostic test in acute appendicitis is $86.6 \%$ and 93.3\% respectively. ${ }^{9}$

Our study showed that CRP had a positive predictive value of $97 \%$ and a negative predictive value of $66 \%$, whereas in a study by Essam et al CRP had a positive predictive value of $55 \%$ and a negative predictive value of $88 \%$. $^{9}$

In our study the PCT values were higher than the upper normal limit in 40(95.2\%) patients where as in the study Bulent kaya et al the PCT values were higher than the upper normal limit in $20(25.6 \%)$ patients ${ }^{6}$.

Khan et al. showed that the serum level of procalcitonin in with suspected acute appendicitis is higher than control group $(1.12 \mathrm{ng} / \mathrm{ml} \pm 3.28$ versus $0.45 \mathrm{ng} / \mathrm{ml} \pm 1.12$ ), but it is not statistically significant $(\mathrm{p}=0.3)^{7}$

In our study it was shown that PCT had a sensitivity and specificity of $95 \%$ and $20 \%$ respectively, whereas in study by Vikrant Dharwal et al PCT had a sensitivity and specificity of $96 \%$ and $100 \%{ }^{10}$, further in a study by Chandel et al where sensitivity and specificity of procalcitonin for diagnosing acute appendicitis was $95.67 \%$ and $100 \%$ respectively. ${ }^{11}$

In our study we observed that procalcitonin has a positive and negative predictive value of $90 \%$ and $50 \%$ respectively, whereas Bulent Kaya et al observed positive and negative predictive value of procalcitonin as $90 \%$ and $30 \%$ for diagnosing $\mathrm{AA}^{6}$, further in study by Vikrant Dharwal et al observed positive and negative predictive value of $100 \%$ and $66.66 \%$ respectively ${ }^{10}$.

CRP, WBC, PROCALCITONIN has a $\mathrm{p}$ value of $0.001,0.02,0.05$ respectively. $p$ value less than 0.05 is considered to be statistically significant. So, the values of WBC, CRP, procalcitonin are statistically significant in diagnosing acute appendicitis

The diagnostic accuracy of crp, wbc, procalcitonin are acceptable since AUC $(>0.5)$, the AUC of wbc, crp, procalcitonin are 0.816,0.741,0.786 respectively.

\section{Conclusion}

Although this study has some limitations, such as having a small sample size for negative appendicitis,

We can conclude that WBC, CRP and Procalcitonin seems to be useful markers in the evaluation of acute appendicitis. We found that elevated serum CRP, Procalcitonin levels and WBC support the surgeon's clinical diagnosis. We recommend CRP and procalcitonin measurement as a routine laboratory test in patients with suspected diagnosis of acute appendicitis. And we suggest that patients with lower abdominal pain and not clinically convincing and in the absence 
of increased inflammatory markers to undergo further imaging.

Procalcitonin and CRP might have the potential to be used in a panel with order to decrease the number of false positive and false negative cases, helps in avoiding negative appendicectomy.

\section{References}

1. Addiss DG, Shaffer N, Fowler BS, Tauxe RV. The epidemiology of appendicitis and appendectomy in the United States. Am J Epidemiol. 1990;132(5):910-25.

2. Schellekens DH, Hulsewe KW, van Acker BA, van Bijnen AA, de Jaegere TM, Sastrowijoto $\mathrm{SH}$, et al. Evaluation of the diagnostic accuracy of plasma markers for early diagnosis in patients suspected for acute appendicitis. Acad Emerg Med. 2013;20(7):703-10.

3. Smink DS, Finkelstein JA, Garcia Pena BM, ShannonMW, Taylor GA, Fishman SJ.Diagnosis of acute appendicitis in children using a clinical practice guideline. J Pediatr Surg. 2004;39(3):458-63.

4. Humes DJ, Simpson J. Clinical Presentation of Acute Appendicitis: Clinical Signs-Laboratory FindingsClinical Scores, Alvarado Score and Derivate Scores. In: Keyzer C, Gevenois PA, editors. Imaging of Acute Appendicitis in Adults and Children. Berlin, Heidelberg: Springer Berlin Heidelberg; 2012. p. 13-21.

5. Yu CW, Juan LI, Wu MH, Shen CJ, Wu JY, Lee CC. Systematic review andmetaanalysis of the diagnostic accuracy of procalcitonin, C-reactive protein and white blood cell count for suspected acute appendicitis. Br J Surg. 2013;100(3):3229.
6. Bulent Kaya, Baris Sana, Cengiz Eris, Koray Karabulut, Orhan Bat, Riza Kutanis Int J Med Sci. 2012; 9(10): 909915. Published online 2012 Nov 13. doi: 10.7150/ijms.4733

7. Khan AN, Sawan A, Likourezos A, Schnellinger M, Garcia E. The usefulness of procalcitonin in the diagnosis of appendicitis in children: a pilot study. Emerg Med Int. 2012;2012:317504.

8. Satendra Kumar, Jayant Maurya, Sandip Kumar, Shashi Kant Patne, and Amit Nandan Dhar Dwivedi A study of Creactive protein and D-dimer in patients of appendicitis J Family Med Prim Care. 2020 Jul; 9(7): 3492-3495.

9. Essam F Ebied, Ebied H. The diagnostic value of C-reactive protein and white blood cell count in diagnosis of acute appendicitis. Egypt J Surg 2016;35:1-4

10. Vikrant Dharwal et al., Evaluation of procalcitonin as a predictor of severity of acute appendicitis. Int Surg J. 2020 Jun;7(6):1879-1885

11. Chandel V, Batt SH, Bhat MY, Kawoosa NU, Yousuf A, Zargar BR. Procalcitonin as the biomarker of inflammation in diagnosis of appendicitis in pediatric patients and prevention of unnecessary appendectomies. Indian J Surg. 2011;73(2):136-41. 